\title{
Cave fauna monitoring and management at Ida Bay, Tasmania
}

\author{
Stefan Eberhard \\ CaveWorks, P.O. Witchcliffe, Western Australia 6286, Australia
}

\begin{abstract}
The Ida Bay karst in southern Tasmania contains a diverse and significant cave fauna. Conservation management of the cave fauna has involved: 1 , legislative protection of rare and threatened species; 2 , protection of sensitive habitats within caves by marking routes and sanctuary areas; and 3 , educating cave users, including teaching of minimum impact caving techniques. Monitoring of cave fauna has been undertaken for the purposes of: 1, gathering baseline ecological information for research, visitor management, and interpretation; 2, measuring the ecological impacts of limestone quarrying and subsequent recovery during rehabilitation efforts.
\end{abstract}

\section{INTRODUCTION}

Owing to the paucity of earlier baseline data and, until recently, a general lack of impact-related studies, it has proved difficult to quantify and manage the effects of various human activities on cave fauna. Nevertheless, there are cases in Australia where human activities have caused the local extinction of cave-dwelling invertebrate populations, or where they have been seriously degraded or compromised (Hamilton-Smith and Eberhard, 2000). Significant threats to cave fauna may involve gross habitat and catchment disturbances associated with, for example, quarrying, forestry, land clearance, agriculture, pollution, and water abstraction. Human visitors in caves may directly impact upon cave fauna by causing disturbance or trampling of populations, habitats or food sources. Research activities such as collecting of too many specimens may compromise the viability of small cave populations. Management activities and tourism development infrastructure, such as gates or doors on cave entrances, may affect cave micro-climate, nutrient inputs and migration of fauna.

The Ida Bay karst system in southern Tasmania contains one of the more diverse and significant cave faunas in Australia's temperate zone (Eberhard et al., 1991; Goede, 1967; Richards and Ollier, 1976). About 100 species of invertebrate are recorded including at least 15 species of which are obligate cave inhabitants, or troglobites (Harrison, 1966; Hickman, 1958; Hunt, 1990; Hunt and Hickman, 1993; Lea, 1910; Moore, 1967, 1972; Richards, 1964, 1972). Conservation threats to the Ida Bay karst include limestone quarrying and human visitors to caves. This paper reviews the strategies developed to manage and monitor the Ida Bay cave fauna.

The Ida Bay karst is developed in Ordovician limestones that outcrop between 50 and $300 \mathrm{~m}$ above sea level (Sharples, 1979). The karst outcrop covers an area of approximately eight $\mathrm{km}^{2}$ but the total surface water catchment area exceeds $40 \mathrm{~km}^{2}$. Cave systems are well developed and consist of both horizontal stream passages and deep vertical shafts that are drained laterally from their base by the horizontal passages. The karst system is composed of four contiguous hydrological subsystems (Kiernan, 1993), which are developed around the major horizontal stream caves - Bradley Chesterman Cave, Loons Cave, Arthurs Folly Cave, and Exit Cave (Figure 1).

During the Second World War, a limestone quarry (Blayney's Quarry) was operated near Mystery Creek Cave. Another limestone quarry (Bender's Quarry) was operated at the saddle between Marble Hill and Lune Sugarloaf. Extinction of Tasmanian Mountain Shrimp Anaspides tasmaniae Thomson and most other aquatic species in Bradley Chesterman Cave by 1990 was probably caused by the severe sedimentation, and/or other disturbances which included flow regime changes, nutrient enrichment and toxins originating from the quarry (Eberhard, 1990, 1995). The quarry was closed down in 1992 as a consequence of the deleterious effects upon cave fauna and other natural heritage values. A rehabilitation programme was implemented to minimise the further influx of sediment and pollutants, and to restore the natural catchment characteristics. Two to three years after rehabilitation had commenced one species of amphipod crustacean had recolonised the cave. By six years, most of the macrofauna had recolonised the cave stream, i.e. $A$. tasmaniae, amphipods, molluscs and planarians (Eberhard, 1999).

Aside from gross catchment disturbances, cavedwelling invertebrates in many caves are also 
Figure 1. Plan of the Ida Bay karst system showing cave passages, drainage relationships, and location of sites mentioned in text.

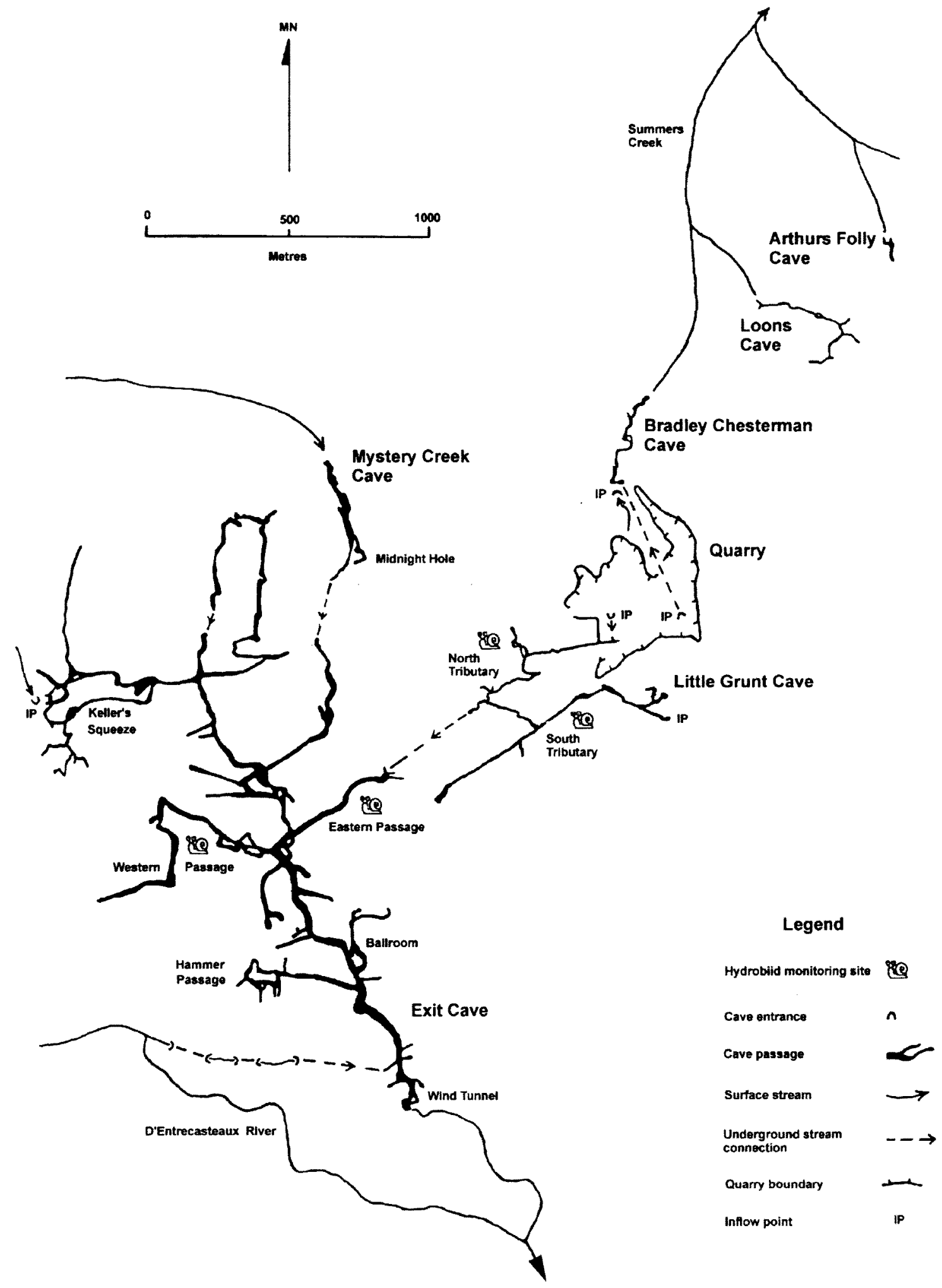

Figure 1 Plan of the Ida bay karst system showing cave passages, drainage relationships, and location of hydrobiid monitoring sites. 
potentially under threat from cave visitors who inadvertently trample them underfoot, cause other disturbances, or cause degradation of habitat. One effect of intensive trampling is the compaction of soft floor sediment that may render it less suitable as invertebrate habitat (Spate and Hamilton-Smith, 1991). Trampling of habitat and individuals has been identified as a possible threat to the blind cave beetle Goedetrechus mendumae at Ida Bay (Invertebrate Advisory Committee, 1994).

Activities associated with scientific research may also be a threat to cave fauna, either through habitat disturbance (Humphreys et al., 1999), or overcollection of specimens (Slaney and Weinstein, 1995). Specimen collection has been suggested as a possible threat to a number of species at Ida Bay (Richards and Ollier, 1976).

\section{MONITORING}

Very little research or monitoring has been undertaken in Australia which specifically relates to the impacts of human visitors upon cave fauna. This probably reflects the difficulty of experimentally proving that impacts on cave fauna have been caused by human presence, given the high degree of natural variability in biological systems, the rarity of many cave species, and the difficulty of working in cave environments. Cave environmental conditions (especially moisture and air currents), food supply, predators, and the natural seasonal and annual variation in these parameters all affect fauna distribution and abundance.

In Tasmania, cave fauna monitoring studies have been established at Ida Bay and Little Trimmer Cave at Mole Creek. The Little Trimmer Cave monitoring program was established to gather baseline ecological, hydrological and climatological information in an undisturbed cave ecosystem. (Eberhard, 1990b; Eberhard and Kiernan, 1991). The results of the ecological monitoring have provided useful life history and behavioural data on cave spiders, crickets and amphipods (Doran et al., 1997; Doran et al., 2001; Richardson et al., 1995).

At Ida Bay, population densities of aquatic hydrobiid snails were monitored in an attempt to detect impacts associated with a limestone quarry operation (Eberhard, 1995). The quarry was closed down in 1992 but monitoring of the snails has continued in conjunction with water quality monitoring as part of the quarry rehabilitation program. The hydrobiids were the easiest group to monitor because of their sessile benthic habits, their wide distribution in stream habitats and their relative abundance.

The initial monitoring studies in Little Grunt Cave and the Eastern Passage of Exit Cave attempted to determine if hydrological changes associated with the quarry were affecting the abundance of snails (Eberhard, 1992a, 1992b, 1993, 1994a, 1994b, 1995). Observations clearly showed that sedimentation derived from the quarry was limiting the distribution of snails by smothering areas of hardbottom stream habitats, and that the physicochemical characteristics of impacted streams were distinct from those of non-impacted streams. A study was undertaken to determine if snail abundance was significantly lower in the sedimentaffected North Tributary and Eastern Passage compared with the South Tributary control streams (Figure 1). It was inferred from the initial results to be the case, although the conclusions remain somewhat equivocal because only one set of data was collected in the time available before closure of the quarry. After the quarry was closed down in 1992, rehabilitation efforts sought to minimize the further influx of sediment underground. Monitoring after closure of the quarry and during the period of rehabilitation works indicated no significant difference in snail densities between impact and control sites. Monitoring in Little Grunt Cave was discontinued in 1995 due to difficulty of access to this site, however, monitoring of snail abundance has continued in the Eastern Passage and Western Passage of Exit Cave on a twice yearly basis since then (Eberhard, 1995).

In this study there was no opportunity to collect pre-impact data, which should encompass several years because natural environmental fluctuations will affect snail densities, so the question could be re-oriented to: has rehabilitation of the quarry resulted in recovery of snail densities? The answer to this question is complicated by the fact that despite the works and control of further sediment inputs, large quantities of sediment still remain in situ in the cave streams, where they can be expected to persist for many years and continue to affect the distribution of snails. A reasonable hypothesis to test was that the difference in density between the impact and control locations in Exit Cave has changed through time as the impacted location was gradually cleared of silt by natural high flow events resulting in the increase of density of snails in the impacted location relative to that in the control location. There is no evidence to suggest that there is a trend in the differences in density between control and impact locations in Exit Cave, but this may be because of slow recovery of snails from sedimentation and the other effects of quarrying and rehabilitation earthworks. However, this needs to be weighed against the possibility that the densities of snails in the impacted Eastern Passage have always been low (Barmuta, 1998).

Despite the difficulties of trying to quantify impacts on cave fauna, three terrestrial cave species - glowworms, cave crickets, and cave spiders were selected for pilot monitoring studies because 
of their wide distribution and abundance throughout the karst system, their potential vulnerability to disturbance by visitors, and the relative ease with which they could be monitored. The monitoring methods consisted of monthly population counts within fixed sites, with additional observations on life cycle stages, feeding and reproductive activity, cave climate and stream flow conditions (Eberhard, 1995).

The glowworm displays in Mystery Creek Cave and Exit Cave are arguably one of the most significant and unique features within the Ida Bay caves, their significance having been recognised for more than a hundred years (Anonymous, 1895; Richards and Ollier, 1976). The only other known place in the world where similar displays occur is at Waitomo Cave in New Zealand. Waitomo Cave glowworms were first monitored in 1975 following a serious decline in their numbers caused by modification to the cave climate and catchment disturbance affecting the cave stream and food supply (Williams, 1975; Pugsley, 1984). However, the New Zealand and Tasmanian experience clearly show that glowworm colonies can successfully survive in public show caves subject to very high levels of human visitation, providing that the cave climate conditions and food supply are maintained.

Similarly, populations of cave spiders and cave crickets dwell in close proximity to pathways and lights of Tasmanian show caves which receive many human visitors each day (Eberhard, 2000). Consequently it is considered unlikely that monitoring of these, or any other species, will necessarily detect changes which can be directly attributed to human visitors, unless there occurs an incident where large numbers of individuals within the monitoring sites are deliberately killed. This statement is made in view of the high degree of natural variability, both temporal and spatial, in cave fauna distribution and abundance, and the anticipated low visitation levels to the undeveloped caves at Ida Bay.

However, the pilot monitoring studies will expand knowledge of the caves biological values; identify environmental seasons, cycles, changes and trends; and provide a baseline upon which to assess the impact of future human activity in the Ida Bay caves. The results will also be a valuable source of information for interpretation.

\section{MANAGEMENT}

\section{Species management}

Assessing the management requirements for individual species at Ida Bay considered their: taxonomic status (described or undescribed); distribution (endemic to Ida Bay, or wider distribution); ecological status (troglobite, troglophile, trogloxene, or accidental); conservation status (IUCN criteria, Threatened Species Protection Act 1995, Tasmania and the National Parks and Wildlife Act 1971, Tasmania); and both macrohabitat and micro-habitat requirements.

The taxa recorded from Ida Bay caves are listed in Eberhard et al. (1991), and Clarke (1997). There is a taxonomic impediment to assessing their conservation status as most (59\%) of the 97 recorded cave dwelling taxa are not identified to the species level. There are three described troglobitic species and, minimally, 12 other troglomorphic taxa which remain undescribed.

The most vulnerable taxa are those with a restricted distribution and highly specific ecological niches. All of the described troglobitic taxa are endemic, or nearly endemic, to the Ida Bay karst. None of the troglophiles, trogloxenes, or accidentals at Ida Bay are known to be locally endemic, although the karst provides optimum habitat for some of them.

A number of the cave taxa occurring at Ida Bay are totally protected under the National Parks and Wildlife Act 1970 (Statutory Rule No. 88 of 1976) and/or listed as 'rare' or 'vulnerable' under the Tasmanian Threatened Species Protection Act 1995. A further 12 other undescribed taxa are considered likely to qualify for listing as 'rare' under the same criteria (Eberhard, 1999).

The highly cave modified beetle, Goedetrechus mendumae Moore, was considered vulnerable until a more detailed assessment of the population size and distribution was made (Eberhard, 1999). Since first collected in 1969, very few specimens had been sighted, and the distribution of the species appeared to be confined to a small section of cave known as Kellers Squeeze in Exit Cave (Figure 1). Concern was expressed that the species might be endangered due to over-collection of specimens, and trampling of the habitat (Clarke, 1997). An intensive search for G. mendumae in 1998 significantly extended the known distribution range throughout the Exit Cave subsystem (Eberhard, 1999). The beetle is rare within its range, or very difficult to observe. However, the species is not considered threatened by caver impacts in view of its extensive distribution throughout the Exit Cave subsystem, the widespread occurrence of suitable riparian habitat and meso-cavernous refugiums, and the comparatively low levels of human disturbance (Eberhard, 1999).

\section{Habitat management}

Given the large amount of undescribed material, a valid and practical strategy which can be pursued is to protect the habitat of taxa or communities. The habitat requirements of cave dwelling species can be defined at different scales, ranging from the macro to the micro level. Terrestrial macro-habitats 
can be defined according to the different cave environmental zones, viz. entrance zone, twilight zone, transition zone, and deep zone (Howarth, 1980, 1983), while aquatic macro-habitats can be classified as pools, or streamways. Isolated pools fed by seepage occur in vadose shaft systems and stream abandoned upper level passages. These pools, and their associated seepage waters, may be colonised by a fauna which is distinct from that in larger streamways, for example, the rare syncarid crustacean, Eucrenonaspides sp. (Eberhard et al., 1991). These often small and patchily distributed habitats are sensitive to trampling impacts - a few careless footsteps may degrade or destroy them.

Streams are a very important macro-habitat because they support an abundant aquatic fauna, and transport the food supply for much of the terrestrial fauna in the transition zone and deep zone. The food sources transported by streams include plant detritus such as wood and leaf litter, and accidental species. The large glowworm colonies in Exit Cave and Mystery Creek Cave for example, are entirely dependent upon streams, which transport their allochthonous food supply of insects with aquatic larval stages. Upper level passages in the deep zone which have been abandoned by streams tend to be poorly colonized by fauna.

Underground streams may be classified as either percolation or non-percolation in origin. Nonpercolation streams display high variance in flow resulting from allogenic streams sinking into cave entrances. Percolation streams have low variance in flow because they are fed by autogenic waters from diffuse seepage through the soil and epikarst (Gillieson, 1996). Flood events and the reworking of sediments are more pronounced in non-percolation streams.

Non-percolation streams may be further classified according to their fluvial energy level. The biological sensitivity to trampling impacts appears to be negatively correlated with stream energy levels. In high energy stream environments, human caused disturbances are often not significant when compared to the reworking of the sediments by natural flood events. Percolation stream habitats are the least energetic and most vulnerable to trampling damage, as evidenced in Loons Cave where trampling has altered the stream habitat from a hard-bottomed substrate to a soft-bottomed substrate, thus severely limiting hydrobiid molluscs which dwell only on hard-bottomed substrates. The classification of stream habitats into percolation or non-percolation and high, medium, or low energy types was developed as a framework around which to map vulnerable habitats and manage trampling impacts (Eberhard, 1999).

Micro-habitats comprise the specific substrates, food sources, or hiding places where species occur.
Some species have very specific micro-habitat requirements (e.g. seepage pools or tree roots), whilst others range widely across a range of different habitats. Some micro-habitats are abundant and widely distributed throughout the Ida Bay karst system, whilst other micro-habitats are rare and localised. Micro-habitats vary in their sensitivity and resilience to trampling impacts.

Recognised micro-habitats/fauna locations which are vulnerable to trampling impacts or other disturbance by cave visitors include: deposits of organic material, such as wood, leaf litter, fungi, animal droppings and carcasses; tree roots and associated symbiotic fungi (Eberhard, 1988); riparian sediment banks; seepages and drip pools; the locations where cave crickets congregate; the moist sediment banks where cave crickets lay their eggs; the locations where cave spiders spin their webs; the locations of glowworm colonies; the flood-prone substrates where some millipedes and symphylids occur.

One micro-habitat which is not threatened by trampling is the mesocaverns. The mesocaverns are the small-sized passages, less than $20 \mathrm{~cm}$ diameter, which are far too small for humans to enter but which may be occupied by invertebrates (Howarth, 1980, 1983). Mesocavernous habitats represent a potentially important refugium, especially in heavily trampled cave passages.

In vadose stream passages, habitats are stratified into four recognisable zones: 1 , stream habitat zone; 2 , riparian habitat zone; 3 , supra-riparian habitat zone; 4, fossil zone (Eberhard, 1999; Deharveng, 2000). The lowest level of the passage contains the stream habitat zone with aquatic habitats and associated aquatic fauna. The next stratum consists of the stream banks which are subject to occasional inundation during floods - the riparian habitat zone. The riparian zone starts with the recent detritus near the stream, and ends with the rotten detritus of the oldest and largest flood episodes - it is an important habitat and food source for terrestrial fauna such as millipedes, symphylids, mites, springtails, slaters, pseudoscorpions, amaurobiid spiders, and beetles. The supra-riparian zone is rarely, if ever, subject to flooding, but its proximity to the moisture and food supplies transported in the streamway mean that it is colonised by fauna. Above the supra-riparian zone is the fossil zone, where the substrate tends to be drier and supports little fauna, if any at all. Recognising and differentiating between these zones is important for defining cave route marking to minimize visitor impacts.

Some food sources and substrates may be highly variable, both on a spatial and temporal scale, whilst others are stable and predictable. Habitat characteristics may vary with changes in surface and cave climate, air flow, stream flow regimes, 
flooding, and food inputs. The fauna responds to these changes by colonizing sites where the food supply and environmental conditions are optimum. Thus, it is difficult to precisely map the locations of some habitats and faunal communities since these may change spatiallyand temporally on a short term (daily, seasonally) or longer term (years, decades, centuries) basis.

The management of cave fauna at Ida Bay primarily depends on the education of cave users and the protection of vulnerable habitats. The issue of cave visitor education was addressed by the production of fact sheets which described and illustrated sensitive fauna and habitats, together with minimum impact caving techniques. Vulnerable habitats were protected by route marking and the designation of fauna sanctuaries. Route marking was achieved with string-line pathways or other markers used to direct and confine foot traffic across areas of sensitive substrate (Eberhard, 1999).

A number of sites at Ida Bay were considered worthy of special protection as fauna sanctuaries because of their vulnerability, or because of their conservation value as examples of optimum, representative, or rare habitat and/or animal communities. Else, due to their value for baseline monitoring and research, or public interpretation. Fauna sanctuaries were closed to general access for cave visitors by placing a string line across the passage with an explanatory sign attached, and clearly indicating that further access was barred except for special purposes such as surveying, or emergency/rescue.

In assessing whether or not to install route markers or establish fauna sanctuaries the following factors were considered: 1 , significance and degree of how representative the habitat is at the level of cave passage, individual cave, and karst subsystem level; 2, likelihood of persistent habitat degradation occurring in relation to anticipated visitation levels; 3 , the protection, or possibility of compromising the protection, of other sensitive cave values nearby or elsewhere in the cave, e.g. sediments, bones, speleothems; 4 , possible interference with recreational caving routes, including possible compromise of safe escape routes during floods for example, or, search and rescue; 5 , aesthetic impacts of route marking upon underground wilderness values. The efficacy of route marking and fauna sanctuaries needs to be periodically reviewed as habitat conditions, cave usage patterns and management requirements change.

\section{Karst system, catchment and fire management}

Both fire and forestry activities have the potential to affect the underground ecology by affecting surface vegetation and soil erosion, flow regimes, sediment and nutrient loads of inflow streams. Fire is not considered a threat to the survival of cave fauna provided that imposed fire regimes are similar to those occurring naturally. Some logging occurred above the cave systems early in the $19^{\text {th }}$ Century, but subsequent logging proposals were halted after consideration of the significant natural values of Exit Cave. Presently, no serious threatening processes to cave fauna have been identified in the Ida Bay karst catchment area, which is protected within a State Reserve, and World Heritage Area (WHA). Exit Cave was included in the Western Tasmania WHA on the basis of its outstanding natural values, which included a rich cave fauna.

\section{DISCUSSION}

Appraisal of the feasibility of using cave fauna as environmental indicators for impact studies and management purposes has raised some important considerations. Firstly, it is very difficult to detect even substantial changes in population size of organisms with low, natural background densities and/or high mobility. Secondly, even when background densities are quite high, several independent control locations would be needed to give a powerful test of changes in population size (Barmuta, 1998). The application of simplistic or generalized methods and models may result in false conclusions being drawn, particularly if individual site characteristics are not carefully considered. Thus, the development of soundly based ecological monitoring requires careful consideration of the specific characteristics and complexities of cave and karst environments.

Present understanding of the nature of karst landscapes emphasizes the importance of the interrelationships between environmental conditions prevailing on the surface and those underground (Gillieson, 1996). Karst systems are complex, threedimensional integrated natural systems comprised of rock, water, soil, vegetation and atmosphere. Management in karst and caves should aim to maintain natural flows and cycles of air and water through the landscape in balance with prevailing climatic and biotic regimes (Watson et al., 1997). A stable natural vegetation cover is pivotal to the prevention of erosion and maintenance of critical soil properties and biological processes.

Despite the difficulties involved with their monitoring and management, the significance and heritage value of invertebrate cave fauna is now being more widely recognized by both land managers and conservation planners. The future management and conservation of cave communities will rest both on a legislative footing and on better public recognition and understanding of the complexities of karst processes and karst environments, achieved through applied research 
and monitoring (Hamilton-Smith and Eberhard, 2000). At Ida Bay, the World Heritage significance of the karst has been acknowledged partly through the development of strategies to improve conservation and management of the cave fauna. The strategies developed include legislative protection, visitor education, and habitat protection, combined with ongoing monitoring.

\section{ACKNOWLEDGEMENTS}

This study was carried out under the direction of the Tasmanian Parks and Wildlife Service and was funded by the Commonwealth of Australia through Environment Australia's World Heritage Program. Particular thanks go to Mike Driessen of the Parks and Wildlife Service for his enthusiastic support throughout the study. The comments of referees who critically reviewed this manuscript are much appreciated.

\section{REFERENCES}

Anonymous (1895). The glow-worm caves of Tasmania. Scientific American 23: 332.

Barmuta, L.A. (1998). Using hydrobiid snails for environmental monitoring and assessment in Tasmanian caves. Unpublished report to Parks and Wildlife Service, Department of Environment and Land Management, Tasmania. $34 \mathrm{pp}$.

Clarke, A. (1997). Management prescriptions for Tasmania's cave fauna. Unpublished report to Tasmanian Regional Forest Agreement (RFA) Environment and Heritage Technical Committee, Hobart. 166 pp.

Culver, D.C. (1982). Cave life: evolution and ecology. Harvard University Press, Massachusetts.

Deharveng, L. and Bedos, A. (2000). The cave fauna of Southeast Asia. origins, evolution and ecology. In $\mathrm{H}$. Wilkens, D.C. Culver and W.F. Humphreys (eds). Ecosystems of the World, Volume 30, Subterranean biota: 603-632. Elsevier, Amsterdam.

Doran, N.E., Eberhard, S.M., Richardson, A.M. and Swain, R. (1997). Invertebrate biodiversity and conservation in Tasmanian caves. Memoirs of the Museum Victoria 56: 649-653.

Doran, N.E., Richardson, A.M. and Swain, R. (2001). The reproductive history of Hickmania troglodytes, the Tasmanian Cave Spider (Araneae, Austrochilidae). Journal of Zoology, London 253: 405-418.

Eberhard, R.S. and Kiernan, K.W. (1991). Little Trimmer Project: instrumented monitoring of the underground environment. In S. Brooks (ed.), Cave Leeuwin 1991, Preceedings of the 18th Biennial Conference of the Australian Speleological Federation: 66-69.

Eberhard, S.M. (1988). Report on the occurrence of an Ascomycete fungus from a cave at Ida Bay. Journal of the Tasmanian Cave and Karst Research Group 2: 29-30.

Eberhard, S.M. (1990a). Ida Bay Karst Study: The cave fauna at Ida Bay in Tasmania and the effect of quarry operations. Unpublished report to Department of Parks Wildlife and Heritage, Hobart. 18pp.
Eberhard, S.M. (1990b). Little Trimmer Cave Project biological monitoring program. Unpublished report to the Forestry Commission, Tasmania. 14 pp.

Eberhard, S.M. (1992a). Investigation of the potential for hydrobiid snails to be used as environmental indicators in cave streams: preliminary draft report. Zoology Department, University of Tasmania .

Eberhard, S.M. (1992b). The effect of stream sedimentation on population densities of hydrobiid molluscs in caves. Unpublished report to Department of Parks, Wildlife and Heritage, Tasmania.

Eberhard, S.M. (1993). Ecological monitoring during rehabilitation of the Ida Bay limestone quarry. Unpublished report to Parks and Wildlife Service, Department of Environment and Land Management, Tasmania.

Eberhard, S.M. (1994a). Ecological monitoring of aquatic cave fauna at Ida Bay in Tasmania: results for May 1994. Unpublished report to Parks and Wildlife Service, Department of Environment and Land Management, Tasmania.

Eberhard, S.M. (1994b). Ecological monitoring of aquatic cave fauna at Ida Bay in Tasmania: results for September 1994. Unpublished report to Parks and Wildlife Service, Department of Environment and Land Management, Tasmania.

Eberhard, S.M. (1995). Impact of a limestone quarry on aquatic cave fauna at Ida Bay in Tasmania. Proceedings of the 11th Australasian Cave and Karst Management Association Conference, Tasmania, May 1995: 125-137.

Eberhard, S.M. (1999). Cave fauna management and monitoring at Ida Bay, Tasmania. Nature Conservation Report 99/1. Parks and Wildlife Service, Tasmania. 37 pp.

Eberhard, S. (2000). Reconnaissance Survey of Cave Fauna Management Issues in the Mole Creek Karst National Park, Tasmania. Nature Conservation Report 2000/1. Parks and Wildlife Service, Tasmania.

Eberhard, S.M. and Hamilton-Smith, E. (1998). Conservation of cave fauna in Australia. Proceedings of the $12^{\text {th }}$ Australasian Cave and Karst Management Association Conference, Waitomo, New Zealand, May 1997: 15-30.

Eberhard, S.M., Richardson, A.M.M. and Swain, R. (1991). The invertebrate cave fauna of Tasmania. Report to the National Estate Office, Canberra. 174 pp.

Gillieson, D.S. (1996). Caves - processes, development, management. Blackwell, Masachusetts.

Goede, A. (1967). Tasmanian cave fauna: character and distribution. Helictite 5: 71-86.

Hamilton-Smith, E. and Eberhard, S. (2000). Conservation of cave fauna in Australia. In $\mathrm{H}$. Wilkens, D.C. Culver and W.F. Humphreys (eds), Ecosystems of the World, Volume 30, Subterranean biota: 647-664. Elsevier, Amsterdam.

Harrison, R.A. (1966). Australian glow-worms of the genus Arachnocampa Edwards (Diptera: Mycetophilidae). Pacific Insects 8: 877-833.

Hickman, V.V. (1958). Some Tasmanian harvestmen of the family Triaenonychidae (sub-order Laniatores). Papers and Proceedings of the Royal Society of Tasmania 92: 1-116. 
Howarth, F.G. (1980). The zoogeography of specialised cave animals: a bioclimatic model. Evolution 34: 394406.

Howarth, F.G., (1983). Ecology of cave arthropods. Annual Review of Entomology 28: 365-389.

Humphreys, W.F., Poole, A., Eberhard, S.M. and Warren, D. (1999). Effects of research diving on the physicochemical profile of Bundera Sinkhole, an anchialine remiped habitat at Cape Range, Western Australia. Journal of the Royal Society of Western Australia 82: 99108.

Hunt, G.S. and Hickman, J.L. (1993). Revision of the genus Lomanella Pocock with implications for family level classification within the Travunoidea (Arachnida: Opiliones: Triaenonychidae). Records of the Australian Museum 45: 81-119.

Hunt, G.S. (1990). Hickmanoxyomma, a new genus of cavernicolous harvestmen from Tasmania (Opiliones: Triaenonychidae). Records of the Australian Museum 42: 45-68.

Invertebrate Advisory Committee (1994). Interim list of native invertebrates which are rare or threatened in Tasmania. Parks and Wildlife Service, Tasmania.

Kiernan, K.W. (1993). The Exit Cave quarry - tracing water flows and resource policy evolution. Helictite 31: 27-93.

Lea, A.M. (1910). On some Tasmanian cave inhabiting beetles. Tasmanian Naturalist 2: 53-58.

Moore, B.P. (1967). New Australian cave Carabidae (Coleoptera). Proceedings of the Linnaean Society of New South Wales 91: 179-184.

Moore, B.P. (1972). A revision of the Australian Trechinae (Coleoptera: Carabidae). Australian Journal of Zoology, Supplementary Series 18: 1-61.

Pugsley, C. (1984). Ecology of the New Zealand glowworm, Arachnocampa luminosa (Diptera: Keroplatidae), in the Glowworm Cave, Waitomo. Journal of the Royal Society of New Zealand 14: 387-407.

Richards, A.M. (1964). The Rhaphidophoridae
(Orthoptera). of Australia, 1: Tasmania. Pacific Insects 6: 217-223.

Richards, A.M. (1972). The distribution and possible origins of Tasmanian cave crickets. Proceedings of the 8th National Conference, Australian Speleological Federation, Hobart 1970. Australian Speleological Federation, New South Wales: 85-87.

Richards, A.M. and Ollier, C.D. (1976). Investigation and report on the ecological protection of Exit Cave near Ida Bay in Tasmania for National Parks and Wildlife ServiceTasmania. Unisearch Ltd., Sydney. 73pp.

Richardson, A.M., Doran, N.E., Eberhard, S.M. and Swain, R. (1995). Bioconservation and Tasmanian cave fauna. Proceedings of the 11th Australasian Cave and Karst Management Association Conference, Tasmania, May 1995. Australasian Cave and Karst Management Association and Parks and Wildlife Service, Hobart: 17-24.

Sharples, C.E. (1979). The Ordovician system in the Ida Bay area. BSc Honours Thesis, University of Tasmania.

Slaney, D.P. and Weinstein, P. (1996). Geographical variation in the tropical cave cockroach Paratemnopteryx stonei Roth (Blattellidae) in North Queensland, Australia. International Journal of Speleology 25: 1-14.

Spate, A. and Hamilton-Smith, E. (1991). Cavers impacts - some theoretical and applied considerations. Proceedings of the 9th Australasian Cave and Karst Management Association Conference. Australasian Cave and Karst Management Association, Margaret River: 20-30.

Watson, J., Hamilton-Smith, E., Gillieson, D. and Kiernan, K. (1997). Guidelines for cave and karst protection. IUCN, Gland, Switzerland and Cambridge, UK. 63 pp.

Williams, P.W. (1975). Report on Waitomo Caves. Bulletin of the New Zealand Speleological Society 5: 374-395.

Manuscript received 28 April 2000; accepted 29 August 2000. 